\title{
Human Peripheral Blood Stem Cells can be a Solution to Diabetes Mellitus Type 2 a Preliminary Study on 14 Patients
}

\section{Ciro Gargiulo1*, Van H Pham², Huynh D Thao ${ }^{3}$, Vo LH Trieu', Nguyen CD Kieu', Melvin Shiffman ${ }^{4}$, Mark J Holtherman ${ }^{5}$ and Sergey K Aityan ${ }^{6}$}

${ }^{1}$ HMIC-Tan Tao University, Ho Chi Minh City, Vietnam

${ }^{2}$ Nam Khoa Bioteck-Tan Tao University, Ho Chi Minh City, Vietnam

${ }^{3}$ Department of Stem Cell Research, Pham Ngoc Thach University of Medicine, Ho Chi Minh City, Vietnam

${ }^{4}$ Plastic Surgeon and Stem Cell Specialist Consultant, Tustin CA, USA

${ }^{5}$ UICOMP, Chicago IL, USA

${ }^{6}$ Lincoln University, Multidisciplinary Research Center, Oakland CA, USA

\begin{abstract}
Background: The use of autologous peripheral stem cell (PB-SCs) in Diabetes Mellitus type 1 (type 1 DM) was described in 2007 with promising conclusion. However a similar treatment with a positive outcome on type 2 diabetes mellitus patients (type $2 \mathrm{DM}$ ) has not been yet reported. The goal of this study was to determine the effect of autologous PB-SCs transplantation in treatment of DM2 patient.
\end{abstract}

Methods: Current study involved 14 patients with type 2 DM (aged 48 to 84 years) during a period of 180 days in our facility. Clinical variables (duration of DM, oral hypoglycemic drugs, time free from oral drugs) and laboratory variables (HbA1c, blood pressure, weight, cholesterol), mononuclear cells infused were assessed. Purified PB SCs were infused into major systemic vein (upper limbs or lower limbs) and subcutaneously in the abdomen. Follow-up is performed weekly after infusion during a period of 6 months.

Results: Mean $\mathrm{HbA1c}$ values showed a significant reduction during follow-up in all patients after autologous PB-SCs. After the treatment with stem cells the HbA1c level dropped by at least one unit relative to the HbA1c level in the medication phase, with stem cells patients have mean value of $\mathrm{HbA} 1 \mathrm{c}$ lower than $6.5 \%$ (Mean value at time of diagnose $8.9 \%$, at time of medication $7.9 \%$ and at time of post stem cell therapy $6.2 \%$ ). Also, it was confirmed that the stem cell treatment is more efficient for the patients with higher $\mathrm{HbA} 1 \mathrm{c}$ level in the medication phase and the level originally diagnosed. In 180 days after the combined therapy, $\mathrm{HbA} 1 \mathrm{c}$, cholesterol, and liver profile stay stable compare to the baseline among those patients who did not continue the LGI diet. All patients were insulin and/or oral hypoglycemic drugs completely free.

Conclusions: Therapy based on autologous PB-SCs can improve glucose control and reduce the dose of insulin and/or oral hypoglycemic drugs in type 2 DM patients, but it only improves pancreatic $\beta$-cell function transiently if the patients would not adjust their diet and life style. Further randomized controlled clinical trials involving more patients will be required to confirm these findings and the mechanism needs to be learned deeper.

Keywords: HPB-SCs; LGI diet; Type 2DM; HbA1c; MSCs; NSCs; ESCs; HSCs

\section{Introduction}

Diabetes is a disorder that strictly belongs to the Metabolic Syndrome (MS) a cluster of metabolic conditions that includes a variety of diseases such as hypercholesterolemia, liver enzyme disorders, atherosclerosis, hypertension, cardio-vascular disease (CVD) that altogether rise the risk of morbidity and life impairment among world population. Diabetes is one of the most silent and threatens disease of the modern time and it is constantly increasing in both industrialized and developing countries [1]. Better economic condition, a more sedentary life style, a higher consumption of polished rice which contains high glycemic index values, a diet richer in starchy processed food and western style-hyper energy food have contributed to a rapid evolvement of DM2 among Vietnamese population, especially in more industrialized cities such as Ho Chi Minh City and Ha Noi [1]. Data from a recent revise in Vietnam confirmed that Diabetes type 2 (DM2) increased $211 \%$ in a little more than a decade from 2002 to 2013 [1]. Today, with more than 3.3 million diabetics Vietnam is among the top ten countries in the world in terms of diabetes prevalence [1]. During the 90's few studies showed that Vietnamese diabetic patients had low or normal body mass index (BMI) and, though nowadays, this index together with obesity and abnormal fat distribution have greatly increased still remain within the normal parameters dictated by WHO [1]. Indeed, scientists have confirmed that the abnormal fat distribution and, not the BMI, have to be considered the main cause of insulin resistance (IR) among Vietnamese diabetic population [1]. Present time cell therapy is basically focused on the use of adult MSCs, stem cells of stromal origin characterized by their multipotency with the ability to self-renew [2,3], differentiate to various cell phenotypes such as osteoblasts, chondrocytes, adipocytes, fibroblasts, tenocytes [4,5], or hepatocytes, neural cells and epithelial cells [6]. Bone marrow MSCs have been the most widely studied, however MSCs can be also isolated, with similar but not identical features, from different tissues including cord blood, umbilical cord, placenta, adipose tissue, trabecular bone, dental pulp and peripheral blood [7-12]. Overall,

*Corresponding author: Ciro Gargiulo, Faculty of Medicine, HMIC-Tan Tao University, Ho Chi Minh City, Vietnam, Tel: +84 723769 216; E-mail: drciroisacco@gmail.com

Received July 26, 2016; Accepted August 12, 2016; Published August 19, 2016

Citation: Gargiulo C, Pham VH, Thao HD, Trieu VLH, Kieu NCD, et al. (2016) Human Peripheral Blood Stem Cells can be a Solution to Diabetes Mellitus Type 2 a Preliminary Study on 14 Patients. J Stem Cell Res Ther 6: 354. doi: 10.4172/2157-7633.1000354

Copyright: (c) 2016 Gargiulo C, et al. This is an open-access article distributed under the terms of the Creative Commons Attribution License, which permits unrestricted use, distribution, and reproduction in any medium, provided the original author and source are credited. 
the ambition of cell-based therapies is to approach with a blend of resources that are aimed basically to restore, repair, or improve the function of damaged cells, tissue, organ, or system, by using intact, amplified, or modified autologous or allogeneic cells [13]. Eventually, hPB present few practical advantages over embryonic, umbilical cord blood, bone marrow or adipose tissue $[13,14]$. We assume that the use of combined stem cells may give few advantages in respect of a single type of cell such as MSCs, ESCs, iPS; by this way we tend to reflect the original microenvironment where these cells growth, develop and interact with each other in a very specific manner. For instance, one of the main limitation of autologous MSCs is in the number of totally characterized cell availability which may represent a major obstacle to their use in stem cell therapy; to reach the optimal number for the in vivo procedure MSCs requires an extensive manipulation in vitro that eventually may compromise the quality, the effectiveness and safety of the cells [15]. The major concerns related to the use of ESCs and iPS remain the high grade of tumorigenic activity as it is common the formation of benign/malignant cystic teratoma from the numerous remaining undifferentiated cells and the ethical concerns of possible destruction of embryos in the process of collecting the ESCs [16].

With regard to the source bone marrow (BM) and adipose tissue (AT) present limitations related to the invasive procedural extraction that may result in to serious complication for the patient. One should also consider that the isolation of AT stem cells it's a multipart, complicated process which requires the use of several numbers of enzymes. The extensive manipulation and the length of the procedure may contribute to a low quality of the obtained stem cells amid increases the possibility of contamination $[13,16]$. In this study we have presented the use of a cluster of stem cells obtained from autologous peripheral blood sample to treat a group of 14 patients with DM II. Our previously edited data have confirmed the presence of four types of stem cells that can be isolated and cultured from peripheral blood sample in a different amount and gradation such as, MSCs, NSCs, HSCs, NSCs and progenitor NK cells CD16-56 [15]. There are differences among data on PB-SCs that could be explained by the dissimilar inference related to patient and their diverse physiological condition. Peripheral blood SCs can self-renew to a certain extent and can differentiate, they can display a variety of significant functions including repair of damaged area and support appropriate cell and tissue renewal to replace the injured tissues. Most intriguingly, these stem cells work in a very interactive mode, supporting each other in all activities they are involved with. Results merged into the field of immunology and endocrinology, with new findings emphasized the role played on both immunologic factors (such as IL-2, IL-6 IFN- $\gamma$, or TNF- $\alpha$ ) and hormones (testosterone, progesterone, estrogen, DHEA, IGF1, TSH, T3-4, leptin, FSH, LH, ACTH and cortisol) in the regulation of the hematopoietic compartment [15].

\section{Stem cells therapy in DM II attempts and results}

Stem cell clinical validity in diabetes care is based on regeneration, rebalance, repair and replacement of damaged islet and vascular endothelial cells [15-17]. This paper will consider the effects of diabetes on resident endogenous stem cells and the potential utility of PB-SCs to treat diabetes in clinical application. Diabetes degeneration mechanism is based on its damage of resident stem cells within the osteoblastic niche within the $\mathrm{BM}$, a process that takes place in two distinctive inter-related moments known as "diabetic stem cell mobilopathy" and "diabetes induces bone marrow micro-angiopathy" which refer to impaired control of stem cell mobilization into the systemic circulation [17-19]. Reduced availability of circulating stem cells and downregulation of endothelial progenitor cells (EPCs) caused by hyperglycemia oxidativestress are among the several important mechanisms accountable for the occurrence of endothelial dysfunction and vascular degeneration in diabetes [20-23]. One of the first regenerative approaches in the cure of DM II, was the idea to replenish deficient pancreatic $\beta$-cells [16]

However, scarcity of donations for pancreas or islet allograft transplantation together with compatibility issues has forced the exploration for alternative cell replacement therapy by using different types of stem cells such as MSCs, ESCs, adult and iPS [16]. Experiments conducted on diabetic animal models have suggested that hyperglycemia could be a crucial step for bone marrow-derived MSCs differentiation into IPCs capable of regularizing with chronic hyperglycemia and cardiomyopathy [24-26]. Hence, it has been argued that a possible effect of MSCs in diabetes has to be related to their ability to generate insulinproducing cells (IPCs) which are capable to express numerous genes in charge of the growth and expansion of pancreatic $\beta$-cells, including high expression of pancreatic and duodenal homeobox 1 , insulin, and glucagon [24,27-29]. Intriguingly, animal models showed to be able to release insulin in a specific glucose-dependent manner that led to amelioration of diabetic conditions [24,28,29]. We also suspect that the insulin resistance and irregular picks of sugar typical of DM-II is due to a multi-layer defection which also includes an insulin defection on pancreatic $\beta$-cells. However, we assume that long term benefits from stem cell treatment are to be correlated to a combined activity of whole stem cells present in the blood stream (HSCs, ESCs, NSCs and MSCs) at different level rather to a single specific group of stem cells, such as MSCs or HSCs.

\section{Low glycemic index diet may help to stabilize and prolong the regenerative effect of stem cells during and after the procedure}

A nutritional approach with a balanced proportion of lipids, proteins and carbohydrates is being investigated with both different macronutrient and micronutrient composition to support the conventional treatment in patients with DN II. Low glycemic index diet (LGI) in the management of diabetes is still under debate, with divergent information around the world [30]. As asserted by the American Diabetes Association the use of low-GI foods may reduce postprandial hyperglycemia however evidence of long-term benefit are not sufficiently strong to recommend the use as a primary strategy. Less cautiously, the European Association for the Study of Diabetes suggests a switch to a low-GI foods almost without reserves [30-32]. Food with low GI $(\leq 70)$ are suggested as prevention to obesity, DM II, and cardio vascular disease (CVD) [33]. And intriguingly, data from a meta-analysis of randomized controlled trials to determine whether low-GI diets compared with conventional or high-GI diets, showed an improvement of overall glycemic control in individuals with diabetes, with a decrease of $\mathrm{HbAlc}$ or fructosamine levels [30]. Associations have also been reported between GI and both unfavorable lipid profiles and raised inflammatory status. The GI of a specific food will vary depending on the rate of digestion, the GI increases as digestion of a food is faster that correlates to a value $>70$ [33]. The GI is affected by a number of factors such as the type of carbohydrate (glucose, maltose, saccharose, and fructose); the fat and protein content (a lower GI is associated with a slowing of gastric emptying); acidity affects gastric emptying and hence the GI of a specific food, the addition of citric acid or other fruits will therefore lower the GI [33].

\section{Material and Methods}

Fourteen patients with oral anti-diabetic drug and insulin $\geq$ $0.4 \mathrm{IU}$ per kg per day with $\mathrm{HbAlc} 7.5-11 \mathrm{HbAlc} \%$ were assigned to 
an intervention group $(\mathrm{n}=13)$ and followed for 6 months. Patients received autologous PB-SCs both sub-cutaneous and through the antecubital vein. The primary end point was a gradual reduction of both oral and insulin requirement by $\geq 100 \%$ from baseline while maintaining $\mathrm{HbAl}<<7 \%$. Ten out of thirteen, (99\%) patients achieved the primary end point during the first quarter after the treatment, whereas one of the patients failed due to high glycemic index diet over the study period $(\mathrm{p}=0.002)$. The drug requirement decreased by $66.7 \%$ in the intervention group from 42.0 (31.0-64.0) IU per day to $14.0(0.0-30.0)$ IU per day $(\mathrm{p}=0.011)$. The reduction in insulin or orally medication requirement was significantly more during the time patient received stem cells compared during the time they received medication $(\mathrm{p}=0.001)$ and 6 months $(\mathrm{p}=0.004)$. Ten out of $13(91 \%)$ patients could maintain $\mathrm{HbAlc}<7 \%$ for the following 6 months. Of note, glucagon-stimulated $\mathrm{C}$-peptide was not considered a significant marker criteria as it was evaluated just after diabetic drug treatment. Therefore decreased drug requirement positively correlated with blood pressure, cholesterol and triglycerides rather than C-peptide $(r=0.8$, $\mathrm{p}=0.001)$. In conclusion, autologous PB-SCs results in a significant decrease in both insulin and oral drug dose requirements along with an improvement in blood pressure, cholesterol, triglycerides levels and average weight in T2DM. However, we are well aware that a greater number of patients with a longer duration of follow-up are required to validate these remarks and results.

\section{Baseline evaluation}

All subjects underwent clinical assessment regarding glycemic control, micro and macrovascular complications. Evaluation at the time of enrollment included blood pressure (BP), body weight, complete $\mathrm{CBC}$, hormone profile including Testosterone, Estradiol, Progesterone, Cortisol, ACTH, Leptin, Insulin, TSH, T4-3 and Vitamin D, lipid profile, TNFalpha, IFNbeta, IL2-4, electrocardiography, echocardiography. The scheme of medications (including oral hypoglycemic drugs, insulin, blood-lipid lowering drugs) was also recorded. HbAlc was measured by Immunoturbidimetry method. Patients were asked to monitor a four-point glucose profile (fasting, $2 \mathrm{hr}$ post-breakfast, postlunch, post-dinner) using the Optium glucometer (Abbott, Mumbai, India) at least once per week with a target of fasting plasma glucose between 70 and $130 \mathrm{mg} / \mathrm{dl}$ and postprandial glucose $\leq 180 \mathrm{mg} / \mathrm{dl}$ four times per day. All the patients were advised LGI diet and a constant physical activity in the form of low and soft exercises for $30 \mathrm{~min}$ per day. The importance of both LGI diet and physical activity was reinforced at each visit, and a schedule with all the data was recorded at each visit.

\section{Treatment procedure: Peripheral blood stem cells isolation}

Mononucleated cells were isolated from consented patient's peripheral blood according to the guidelines of Helsinki Declaration. Mononucleated cells were isolated by density gradient centrifugation using Ficoll-Paque ${ }^{\mathrm{ma}}$ PLUS (GE Healthcare, Uppsala, Sweden). A total of 10 blood samples ( $35 \mathrm{ml}$ each) were carefully layered 1:2 on FicollPaque and centrifuged at $300 \mathrm{~g}$ for $20 \mathrm{~min}$ at $20^{\circ} \mathrm{C}$. The mononucleated cell layer, $2 \times 10^{7}$, at the plasma-Ficoll interface, were aspired and was washed three times with phosphate buffered saline and cultured in $25 \mathrm{~T}$ flasks with free serum medium containing $2 \%(\mathrm{v} / \mathrm{v})$ penicillinstreptomycin at $37^{\circ} \mathrm{C}$ in a humidified atmosphere containing $5 \% \mathrm{CO}_{2}$ for a period of 7.3 days. Suspension and adherent mononucleated cells were cultured in free serum medium (FSM-Life,TechnologyCTSTM-StemProR, Canada). For both suspension and adherent mononucleated cells, the trypan blue exclusion assay was used to observe the proliferation of the cells. Cells were cultured for 7.3 day average, subsequently suspension and adherent cells were collected and injected to patient. PB-SCs have undergone a series of test to evaluate the feasibility and safety of the therapy. The patients' cell samples were tested for Bacteriology, Fungal and Virology contamination prior infusion.

\section{Results}

\section{General parameters}

Fourteen type DM2 patients were enrolled in the study between January 2014 and January 2016. The mean age was 62 years (48 to 84 years). Nine patients (69\%) were male and 4 patients (31\%) were female. Pretreatment and follow-up characteristics of patients are showed in table. Mean body weight before autologous PB-SCs was $68 \mathrm{Kg}$ (range from 58 to $87 \mathrm{Kg}$.) at the time of initial diagnosis. Mean HbAlc before PB-SCs was 7.8 (range from 6\% to 10.2\%). The mean number of infused mononuclear cells was $3.76 \times 10^{8} / \mathrm{ml}$. The follow-up was performed in six months from the end of the treatment (Figure 1).

\section{Administration of PB-SCs for clinical use}

There are different potential routes for delivery of PB-SCs, the procedure can be performed either by systemic, parenteral, subcutaneous or direct application or injection into the targeted tissue site for regeneration and repair and is reliant on the type of disease or injury. In general the all types of stem cells express cytokine and chemokine receptors on their cell surface and through this way chemotactic gradients secreted by the inflamed tissue allow them to migrate to the site of the damaged tissue [34]. However, it still unclear the quantity of PB SCs that are able to migrate to the targeted tissues following systemic administration. It has been shown that intravenous administration of AT SCs for instance form aggregates in the lungs, liver, heart and brain. Therefore, an increase in the number of injected cells could be the main cause of pulmonary emboli, heart artery occlusion and infarctions or disruption of normal blood flow [34]. As an alternative option we decided for both systemic (forearm cubital vein) and abdomen sub-cutaneous delivery with the intention to imitate exogenous administration of insulin and re-educate systemically the cells that should correctly respond to insulin stimuli and sugar uptake. The clinical administration was divided in a total of 10 sessions during a period of 10 days ( 1 time $=1$ day). Suspension and adherent mononucleated cells were cultured in free serum medium for a period of 7.3 days then cells were collected and injected to patient as above mentioned. Prior to the stem cell treatment, around 7 to 10 days, each patient was suggested to start the diet.

\section{Low glycemic index diet recommendation}

A detailed protocol was designed earlier. The main goal was whether low-GI diets, compared with conventional or high-GI diets, improved
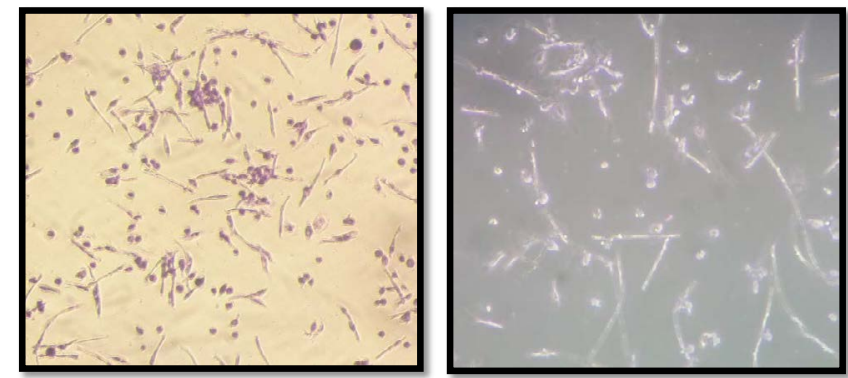

Figure 1: Primary hPB-SCs 100x 12 days culture (pic.1 Giemsa stain; pic. 2 no stain). 
Citation: Gargiulo C, Pham VH, Thao HD, Trieu VLH, Kieu NCD, et al. (2016) Human Peripheral Blood Stem Cells can be a Solution to Diabetes Mellitus Type 2 a Preliminary Study on 14 Patients. J Stem Cell Res Ther 6: 354. doi: 10.4172/2157-7633.1000354

Page 4 of 9

overall glycemic control in individuals with diabetes receiving PBSCs treatment, as assessed by reduced HbA1c or glucose levels in post prandial condition (data not shown). The high-GI diet was defined based on those food containing starches, high refined and processed carbohydrates from low-GI sources, such as pasta, cakes or desserts, white bread, white rice, dairy products, canned food, nuts, potatoes and carbonated drinks as beer and spirits. Low-GI regimen was essentially standard diabetic diet and contained, whole wheat meals bread, vegetables, fresh foods, fish, poultry, red meat and whole brown rice. Changes in both HbAlc and fasting blood glucose level were used as the outcome measures because both reflect overall glycemic control.

\section{Oral hypoglycemic drugs and insulin requirements}

Four patients used oral insulin injection plus oral drugs to reduce HbAlc to mean level of $7.7 \%$ (range from $8.3 \%$ to $6 \%$ ) before PB-SCs. Thirteen patients quit oral and injection hypoglycemic drugs and
HbA1c were reduced to mean level of 6.2 (range from 5.2 to 7.1 ) at the end of the follow-up. Patients were followed up from 4-12 months and did not use any hypoglycemic therapy for 12 months after BMT.

The dynamics of HbAlc level for the thirteen patients is shown in Table 1. The table presents also the $\mathrm{HbAlc}$ absolute and percentage drop in each phase of treatment. Abbreviation "InD" stands for "Initially diagnosed", "Med" stands for "After conventional medication including insulin injections," and "SC" for "After treatment with stem cells". The SC phase always followed the Med phase.

The patients' HbAlc, weight, cholesterol, triglyceride, and blood pressure changes before and after PB-SC are shown in Table 2. Patients' weight and age in Tables 1 and 2 are shown at a time of the first appointment for the treatment with stem cells. The percentage drop of $\mathrm{HbA1c}$ in different phases of the treatment is shown in Table 3 and illustrated in Figure 2. As it is evident from Table 3 and Figure 2 the

\begin{tabular}{|c|c|c|c|c|c|c|c|c|c|c|c|}
\hline \multicolumn{3}{|c|}{ Patient } & \multicolumn{3}{|c|}{ HbA1c Level } & \multicolumn{3}{|c|}{ HbA1c Dropped by } & \multicolumn{3}{|c|}{ HbA1c Percentage Drop } \\
\hline$\#$ & Gender & Age & $\ln \mathrm{D}$ & Med & sc & InD-Med & Med-SC & InD- SC & InD-Med & Med-SC & InD-SC \\
\hline 1 & Female & 64 & 9.3 & 6.0 & 5.9 & 3.3 & 0.1 & 3.4 & $35 \%$ & $2 \%$ & $37 \%$ \\
\hline 2 & Female & 65 & 9.0 & 8.3 & 7.1 & 0.7 & 1.2 & 1.9 & $8 \%$ & $14 \%$ & $21 \%$ \\
\hline 3 & Male & 73 & 8.0 & 7.5 & 6.5 & 0.5 & 1.0 & 1.5 & $6 \%$ & $13 \%$ & $19 \%$ \\
\hline 4 & Female & 54 & 9.8 & 9.6 & 5.2 & 0.2 & 4.4 & 4.6 & $2 \%$ & $46 \%$ & $47 \%$ \\
\hline 5 & Male & 66 & 11.0 & 10.2 & 5.4 & 0.8 & 4.8 & 5.6 & $7 \%$ & $47 \%$ & $51 \%$ \\
\hline 6 & Female & 84 & 7.4 & 6.0 & 5.9 & 1.4 & 0.1 & 1.5 & $19 \%$ & $2 \%$ & $20 \%$ \\
\hline 7 & Male & 50 & 10.0 & 8.3 & 6.3 & 1.7 & 2.0 & 3.7 & $17 \%$ & $24 \%$ & $37 \%$ \\
\hline 8 & Male & 62 & 7.2 & 6.7 & 6.7 & 0.5 & 0.0 & 0.5 & $7 \%$ & $0 \%$ & $7 \%$ \\
\hline 9 & Male & 48 & 8.9 & 8.4 & 6.1 & 0.5 & 2.3 & 2.8 & $6 \%$ & $27 \%$ & $31 \%$ \\
\hline 10 & Male & 56 & 8.8 & 8.1 & 6.0 & 0.7 & 2.1 & 2.8 & $8 \%$ & $26 \%$ & $32 \%$ \\
\hline 11 & Male & 60 & 10.0 & 8.9 & 7.1 & 1.1 & 1.8 & 2.9 & $11 \%$ & $20 \%$ & $29 \%$ \\
\hline 12 & Male & 62 & 6.7 & 6.3 & 6.2 & 0.4 & 0.1 & 0.5 & $6 \%$ & $2 \%$ & $7 \%$ \\
\hline 13 & Male & 68 & 8.5 & 7.1 & 6.4 & 1.4 & 0.7 & 2.1 & $16 \%$ & $10 \%$ & $25 \%$ \\
\hline 14 & Male & 73 & 8.0 & 7.3 & 6.3 & 0.7 & 1.0 & 1.7 & $9 \%$ & $14 \%$ & $21 \%$ \\
\hline \multicolumn{2}{|c|}{ Mean: } & 69 & 8.8 & 7.8 & 6.2 & 1.0 & 1.5 & 2.5 & $11 \%$ & $18 \%$ & $27 \%$ \\
\hline \multicolumn{2}{|c|}{ St.Dev.: } & 8 & 1.2 & 1.3 & 0.5 & 0.8 & 1.5 & 1.5 & $9 \%$ & $15 \%$ & $13 \%$ \\
\hline \multicolumn{2}{|c|}{ Max: } & 84 & 11.0 & 10.2 & 7.1 & 3.3 & 4.8 & 5.6 & $35 \%$ & $47 \%$ & $51 \%$ \\
\hline \multicolumn{2}{|c|}{ Min: } & 48 & 6.7 & 6.0 & 5.2 & 0.2 & 0.0 & 0.5 & $2 \%$ & $0 \%$ & $7 \%$ \\
\hline
\end{tabular}

Table 1: HbA1c dynamics through treatment phases. InD - initially diagnosed, Med - after conventional medication, $\mathrm{SC}$ - after treatment with stem cells.

\begin{tabular}{|c|c|c|c|c|c|c|c|c|c|c|c|c|}
\hline \multirow[t]{2}{*}{ \# } & \multirow[t]{2}{*}{ Gender } & \multirow[t]{2}{*}{ Age } & \multicolumn{2}{|c|}{ Weight $\mathrm{Kg}$} & \multicolumn{2}{|c|}{ Cholesterol (mmol/L) } & \multicolumn{2}{|c|}{ Triglyceride (mmol/L) } & \multicolumn{2}{|l|}{ HbA1c } & \multicolumn{2}{|c|}{ Blood Pressure } \\
\hline & & & Before & After & Before & After & Before & After & Before & After & Before & After \\
\hline 1 & Female & 64 & 63 & 62 & 8.3 & 4.1 & 6.2 & 1.3 & 6 & 5.9 & $130 / 80$ & $120 / 80$ \\
\hline 2 & Female & 65 & 58 & 52 & 5 & 5.1 & 3.6 & 3.7 & 8.3 & 7.1 & $110 / 70$ & $110 / 60$ \\
\hline 3 & Male & 73 & 69 & 63 & 4.3 & 3.7 & 1.7 & 1.3 & 7.5 & 6.5 & $130 / 80$ & $120 / 80$ \\
\hline 4 & Female & 54 & 60 & 55 & 4.8 & 4.1 & 3.3 & 1.3 & 9.6 & 5.2 & $140 / 80$ & $130 / 70$ \\
\hline 5 & Male & 66 & 66 & 62 & 5 & 4.6 & 6.2 & 2.1 & 10.2 & 5.4 & $140 / 80$ & $130 / 80$ \\
\hline 6 & Female & 84 & 66 & 58 & 3.9 & 2. 9 & 1.2 & 1.2 & 6 & 5.9 & $130 / 70$ & $110 / 70$ \\
\hline 7 & Male & 50 & 63 & 60 & 4.6 & 4. 4 & 1.9 & 1 & 8.3 & 6.3 & $140 / 90$ & $130 / 80$ \\
\hline 8 & Male & 62 & 74 & 72 & 3.6 & 3.9 & 1.3 & 2.1 & 6.7 & 6.7 & $180 / 110$ & $160 / 70$ \\
\hline 9 & Male & 48 & 68 & 60 & 4.3 & 4.2 & 4.5 & 3.2 & 8.4 & 6.1 & $160 / 110$ & $140 / 70$ \\
\hline 10 & Male & 56 & 75 & 67 & 10.8 & 4.5 & 4.7 & 4.7 & 8.1 & 6 & $120 / 80$ & $120 / 70$ \\
\hline 11 & Male & 60 & 73 & 69 & 6.5 & 4.5 & 3.8 & 1.3 & 8.9 & 7.1 & $140 / 90$ & $120 / 80$ \\
\hline 12 & Male & 62 & 68 & 66 & 7.7 & 3.3 & 2.3 & 3.3 & 6.3 & 6.2 & $100 / 70$ & $120 / 70$ \\
\hline 13 & Male & 68 & 87 & 82 & 3.5 & 4.4 & 8.7 & 3.2 & 7.1 & 6.4 & $130 / 85$ & $120 / 75$ \\
\hline 14 & Male & 73 & 65 & 61 & 1.2 & 1.2 & 1.7 & 1.6 & 7.3 & 6.3 & $130 / 85$ & $110 / 75$ \\
\hline \multicolumn{2}{|c|}{ Mean: } & 63 & 68 & 64 & 5.3 & 3.9 & 3.7 & 2.2 & 7.8 & 6.2 & & \\
\hline \multicolumn{2}{|c|}{ St.Dev.: } & 9.7 & 7.4 & 7.5 & 2.4 & 1 & 2.2 & 1.2 & 1.3 & 0.5 & & \\
\hline \multicolumn{2}{|c|}{ Max: } & 84 & 87 & 82 & 10.8 & 5.1 & 8.7 & 4.7 & 10.2 & 7.1 & & \\
\hline \multicolumn{2}{|c|}{ Min: } & 48 & 58 & 52 & 1.2 & 1.2 & 1.2 & 1 & 6 & 5.2 & & \\
\hline
\end{tabular}




\begin{tabular}{|c|c|c|c|}
\hline Treatment Phase & $\begin{array}{c}\text { Mean } \\
\text { Value }\end{array}$ & $\begin{array}{c}\text { Standard } \\
\text { Deviation }\end{array}$ & $\begin{array}{c}\text { Percentage } \\
\text { Drop }\end{array}$ \\
\hline Initially Diagnosed & 8.8 & 1.2 & -- \\
\hline After Medication & 7.8 & 1.3 & $11 \%$ \\
\hline After Stem Cells & 6.2 & 0.5 & $18 \%$ \\
\hline
\end{tabular}

Table 3: Mean value of $\mathrm{HbA} 1 \mathrm{c}$ for patients at the time of initial diagnosis, after treatment with the conventional medication including insulin injections, and after stem cells.

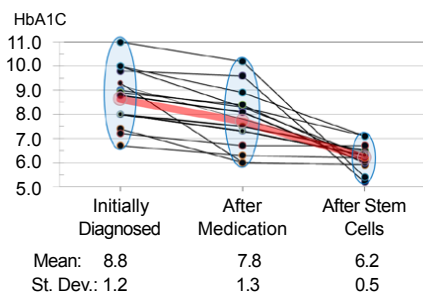

(a) (b)

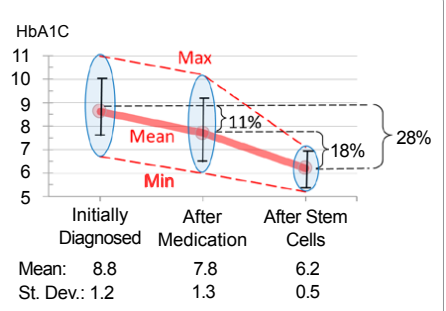

Figure 2: Shows the $\mathrm{HbA1c}$ reduction after the treatment with conventional medication including insulin injections and after PB-SC treatment. The HbA1c dynamics for each of the thirteen patients is shown in Figure 2a, while the dynamics of the mean level of $\mathrm{HbA} 1 \mathrm{c}$ for the group is shown in Figure $2 \mathrm{~b}$.

efficiency of the PB-SC treatment is much higher than the the efficiency of treatment by conventional medication including insulin.

\section{Statistical Analysis}

\section{Statistical significance of the results}

To analyze the statistical significance of the results, let's formulate and test the related hypotheses.

The hypotheses were tested with the significance level of $99 \%$ $(\alpha=0.01)$. The paired Student t-test was used for the following reasons:

- The Student t-test was used because the sample size was too small to suggest normal distribution.

- The paired test was used because both measurements, before and after the treatment were conducted on the same group of patients, so the measurements were paired.

\section{Hypothesis 1}

The null hypothesis: The mean value of $\mathrm{HbAlc}$ after the treatment with PB-SC is not different from the mean value of HbAlc before the treatment.

The alternative hypothesis: The mean value of $\mathrm{HbAlc}$ after the treatment with PB-SC is lower than the mean value of $\mathrm{HbAlc}$ before the treatment.

The paired two sample t-test for means on null hypothesis 1 leads to the results shown in Table 4 . The test was one-tailed because the alternative hypothesis suggested an improvement, i.e. a reduction of HbAlc level.

According to the $\mathrm{t}$-test results, $\mathrm{t}$-Stat $>\mathrm{t}$-Critical value, thus the null hypothesis is rejected and the alternative hypothesis is accepted. Thus the null hypothesis stated that the mean values of $\mathrm{HbAlc}$ for the group before and after the PB-SC treatment failed the t-test with significance level $\alpha=0.01$ (confidence 99\%). That means that the mean value of $\mathrm{HbA1c}$ in the measurements after the PB-SC treatment is significantly lower than the mean value before the treatment.

Given that the mean values of $\mathrm{HbAlc}$ before and after the PB-
SC treatment are different, the following hypothesis is formulated according to the mean values of HbA1c shown in Table 3.

\section{Hypothesis 2}

The main hypothesis: The mean value of $\mathrm{HbAlc}$ after the treatment with PB-SC is at least 1.5 lower than the mean value of $\mathrm{HbA} 1 \mathrm{c}$ before the treatment.

The alternative hypothesis: The difference between the mean values of HbAlc before and after the treatment with PB-SC is lower than 1.5.

The paired two sample t-test for means on Hypothesis 2 leads to the results shown in Table 5. This t-test was also one-tailed to test the reduction of the $\mathrm{HbAlc}$ level. According to the t-test results, i.e. $-\mathrm{t}$-Critical $<\mathrm{t}$-Stat $<\mathrm{t}$-Critical, the main hypothesis 2 is accepted. It means that with significance $\alpha=0.01$ (confidence 99\%) one can say that $\mathrm{HbAlc}$ dropped by at least 1.5 after the PB-SC treatment versus the HbA1c level before the treatment.

\section{Treatment efficiency versus HbAlc level before treatment}

Efficiency of PB-SC treatment can be analyzed by the comparison of the level and the reduction of HbAlc in PB-SC treatment versus the reduction in the phase of treatment by the conventional medication including insulin injections. As it is evident form Figures 3 and 4, PB$\mathrm{SC}$ works better with the higher level of $\mathrm{HbAlc}$ before the treatment than the traditional medication. Figure 3 shows that HbA1c level after PB-SC treatment and the treatment with traditional medication while Figure 4 shows absolute (a) and percentage (b) drop of the HbAlc levels after treatment with $\mathrm{PB}-\mathrm{SC}$ and traditional medication. According to the dependencies shown in Figures 3 and 4 it is clear that PB-SC is more efficient than traditional medication and PB-SC is more efficient with the higher levels of $\mathrm{HbAlc}$ before the treatment.

The analysis above indicates that treatment with stem cells is more efficient than treatment with the traditional medication including insulin injections. This conclusion is supported by a very high positive

\begin{tabular}{|c|c|c|}
\hline Test with $\boldsymbol{\alpha}=\mathbf{0 . 0 1}$ (significance 99\%) & $\begin{array}{c}\text { Variable 1 (HbA1c } \\
\text { Before) }\end{array}$ & $\begin{array}{c}\text { Variable 2 (HbA1c } \\
\text { After) }\end{array}$ \\
\hline Mean & 7.8 & 6.2 \\
\hline Variance & 1.69 & 0.30 \\
\hline Sample size & 14 \\
\hline Pearson Correlation & -0.23 \\
\hline Hypothesized Mean Difference & 0 \\
\hline Degrees of Freedom & \multicolumn{2}{|c|}{13} \\
\hline t-Stat & \multicolumn{2}{|c|}{3.80} \\
\hline P (T $\leq \mathrm{t}$ ) one-tailed & 0.001 \\
\hline t-Critical one tail & 2.65 \\
\hline
\end{tabular}

Table 4: Paired two sample t-Test for means with null hypothesis 1.

\begin{tabular}{|c|c|c|}
\hline Test with $\boldsymbol{\alpha}=\begin{array}{c}\mathbf{0 . 0 1} \text { (significance } \\
\mathbf{9 9 \% )}\end{array}$ & $\begin{array}{c}\text { Variable 1 (HbA1c } \\
\text { Before) }\end{array}$ & $\begin{array}{c}\text { Variable 2 (HbA1c } \\
\text { After) }\end{array}$ \\
\hline Mean & 7.8 & 6.2 \\
\hline Variance & 1,69 & 0.30 \\
\hline Sample size & 14 & 14 \\
\hline Pearson Correlation & \multicolumn{2}{|c|}{-0.23} \\
\hline Hypothesized Mean Difference & 1.5 \\
\hline Degrees of Freedom & \multicolumn{2}{|c|}{13} \\
\hline $\mathrm{t}$-value & \multicolumn{2}{|c|}{0.106} \\
\hline $\mathrm{P}(\mathrm{T} \leq \mathrm{t})$ one tail & \multicolumn{3}{|c|}{0.459} \\
\hline $\mathrm{t}-$-Critical one tail & \multicolumn{3}{|c|}{2.65} \\
\hline
\end{tabular}

Table 5: Paired two sample t-Test for means on Null Hypothesis 2. 


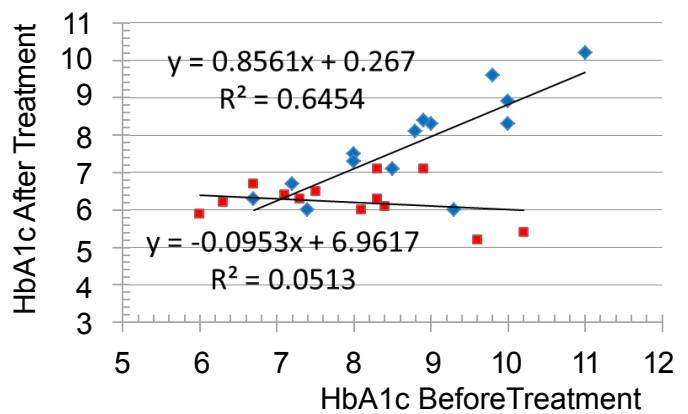

- After Medication - After Stem Cells

Figure 3: $\mathrm{HbA} 1 \mathrm{c}$ level after the treatment by conventional medication (Blue markers) and PB-SC (Red markets).

correlation between percentage drop of $\mathrm{HbAlc}$ level after stem cells vs the level in medication phase, $\mathrm{r}=0.94$ and high positive correlation between percentage drop of $\mathrm{HbAlc}$ level after stem cells vs the initially diagnosed HbAlc level, $r=0.78$ (Figures 5 and 6).

\section{Treatment efficiency versus patient's age}

As shown in Figure 7a the treatment efficiency in terms of HbAlc percentage drop after treatment with conventional medication relative to the initially diagnosed level against the patient's age as shown in Figure $7 \mathrm{~b}$.

The analysis of relationships in Figures $7 \mathrm{a}$ and $7 \mathrm{~b}$ provides clear evidence that conventional medication is more efficient on elder patients while PB-SC is more efficient on younger patients. The HbAlc percentage drop after treatment with the conventional medication and the patient age shows low-medium positive correlation with the correlation coefficient, $r=0.27$. On the other hand, the $\mathrm{HbAlc}$ percentage drop after treatment with the PB-SC and the patient's age show a medium negative correlation with the correlation coefficient, $\mathrm{r}=-0.47$.

\section{Discussion and Conclusion}

The current study may open the possibility of using autologous PBSCs in the treatment of Metabolic Syndrome linked disorders such as DM2. Here, the main question to set on public debate is the fact that the clinical use of stem cells, independently from the source, it requires an overall change of perspective in respect to more conventional way of treatments. The value of PB-SCs and mesenchymal stem cells (as important component of hPB-SCs) is the unique immune- modulatory feature and their activity on stimulating immune response by inducing the activity of immune cells during virus or bacteria invasion $[35,36]$. The simple epistemological concept is to recognize that stem cell therapy should not be restricted within the parameters of a conventional drug therapy. Therefore, due to the complexity of the matter and extraordinary biological character of PB-SCs we are firmly convinced that a multidisciplinary approach composed by molecular biologists, immunologists, dieticians and endocrinologists would be of great value in PB-SCs understanding and future clinical applications.

Type 2 diabetes patients face two main problems, the loss of capacity of absorbing sugar molecules and producing insulin at a correct pace and the high predisposition to infections, malignancy and chronic inflammatory responses [35,37]. The unremitting spike in sugar level, known as "roller coaster" is an event that tends to negatively affect the generation of well-functioning beta cells, an inclination which may be related to either a type of inheritance mechanism or to a long term rich sugar-carbohydrates diet. The highly oxidative diabetic environment depletes the host microcellular homeostatic balance, and the restoration of which is a necessity to improve the reparative function of organs, tissues and cells [38,39]. It is well known the relation between immune deficiencies and hyperglycemia a mechanism mainly related to the decrease of neutrophil degranulation in healthy subjects and the downregulation of LPS-induced activation pathway, as well as interleukin$1 \alpha$ production $[40,41]$. Thus in DM2, beside the pancreatic $\beta$ cell deficiency also the intra/extra cellular/molecular microenvironment may experience complications in the communicating mechanism leading to the insulin resistance mechanism. The chronic inflammatory state associated to DM2 and the continuous "roller coaster" episodes in insulin/glucose relation may elicit the production of abnormal cell clones from primary stem cells that may carry a failure in both intra and extracellular receptor pathway that eventually compromise the sugar/ insulin mechanism route. These types of mutations are often seen in those tissues exposed to constant and abnormal stimuli, as in Barret's Esophagus for instance, where the esophagus mucosa undergoes to an anomalous transformation, dysplasia, due to constant exposure to stomach contents. Therefore, a beneficial effect of autologous SCs may be explained by their uncompromised status that still preserves their ability under optimal physiological/biological conditions, to originate clones without insulin receptor disturbances.

It became clear now how the optimal condition of host cellular microenvironment would be the essential pre-existing criteria for the success of the cell-based therapy. This ideal rich milieu allows adhesion and viability of cells that requires interaction of cell surface molecules with extracellular matrix proteins. Many authors suggest the opportunity of using antioxidants or BM mobilizing agents as option to

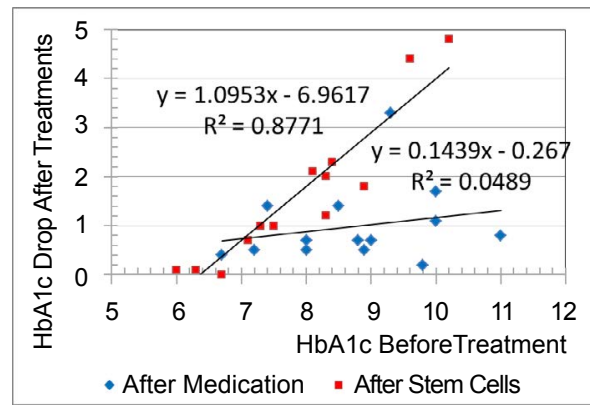

(a)

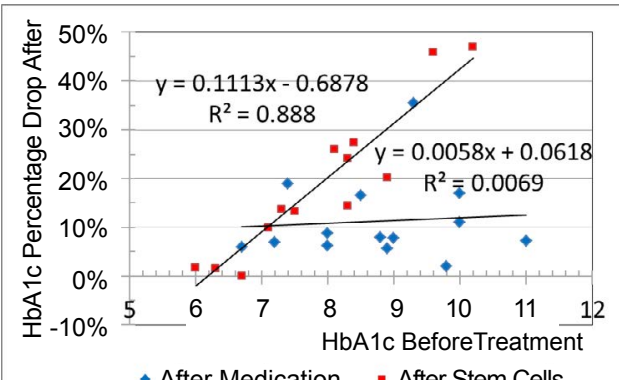

- After Medication - After Stem Cells

(b)

Figure 4: $\mathrm{HbA1c}$ absolute (a) and percentage (b) drop after treatment vs the $\mathrm{HbA1c}$ level before the treatment. 


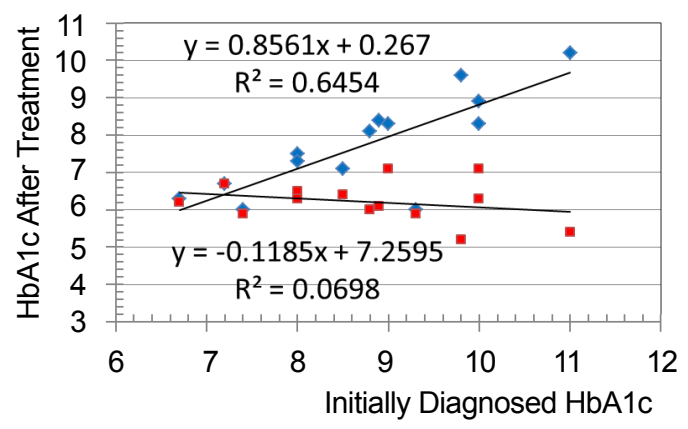

- After Medication - After Stem Cells

Figure 5: HbA1c level after the treatment by conventional medication (Blue markers) and PB-SC (Red markets) versus the initially diagnosed $\mathrm{HbA} 1 \mathrm{c}$ level. $\mathrm{HbA1c}$ level after treatment with the conventional medication as a function of the initially diagnosed level of $\mathrm{HbA} 1 \mathrm{c}$ and Figure 4 shows the absolute (a) and percentage (b) drop of the $\mathrm{HbA} 1 \mathrm{c}$ level versus the initially diagnosed level of $\mathrm{HbA1c}$. Similarly to Figures 3 and 4 , the dependencies in Figures 5 and 6 provide strong evidence of high efficiency of the PB-SC treatment.

achieve better results after and during the therapy [39]. Here we should mention the beneficial support of the LGI diet in maintaining a well balance insulin/glucose level helping in reducing pro-inflammatory responses. The beneficial effect of LGI diet on stem cell therapy could be related to its effect on promoting a better microcellular environment that enhances stem cell immune modulatory activity by increasing their capacity of producing CD16-56 (progenitor NK cells), MSCs known to take in bacteria and eliminate them through apoptosis and autophagy and, anti-inflammatory interleukins such as IL 4-6 and hormones $[15,30-32,38,42]$. The treatment of 14 patients included in our study diagnosed with long term DM2 resulted in a significant drop of the $\mathrm{HbAlc}$ level for all patients together with better outcome in weight loss, cholesterol and triglycerides within a period of 4 months and at 6 months follow up (Table 2). The main endpoint included changes in the oral anti-diabetic drugs and/or insulin dosage. The patients that received therapy started to reduce the amount of medication from the 3rd to 4th injection of autologous PB-SCs to complete stop by the end of the 10th injection, eventually their blood sugar level and $\mathrm{HbA} 1 \mathrm{c}$ tended to normalize within a month soon after the 10 infusion treatment (Table 3).

With the average $\mathrm{HbAlc}$ level equal to 8.8 for the patients at the time of initial diagnostics, HbA1c level dropped to 7.8 after the treatment with traditional medications and resulted in 6.2 after the treatment with stem cells. The standard deviation of $\mathrm{HbAlc}$ after the treatment with stem cells among the patients is 0.5 that indicates a much narrower spread of the results than after the treatment with the traditional medications when the standard deviation of $\mathrm{HbAlc}$ was 1.3 among the same patients (Table 4). Treatment with stem cells is almost equally efficient for all levels of $\mathrm{HbAlc}$ before the treatment. As the result of the treatment, our patients, on average, lost about $6 \%$ of their weight due to the diet, their cholesterol level dropped by $26 \%$, the triglyceride level dropped by $40 \%$, and HbAlc level dropped by $20 \%$. Also, the blood pressure dropped significantly. We also noticed that the results of treatment with stem cell are much better for younger patients in our group, which could be explained by several factors not necessarily related to the patients' age.

As described above, autologous peripheral blood stem cell therapy in diabetics requires the ex vivo change of food regimen for better internal environment outcome regardless of the cell type selected. The

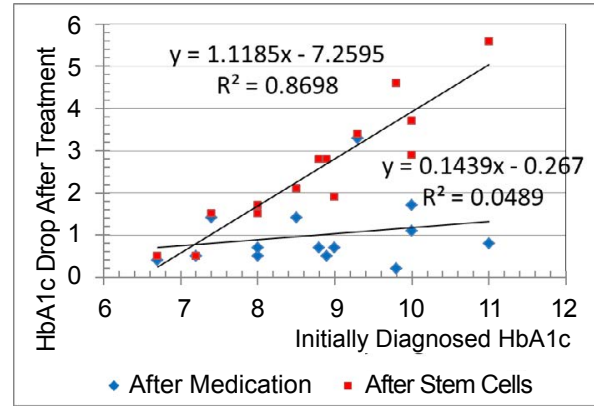

(a)

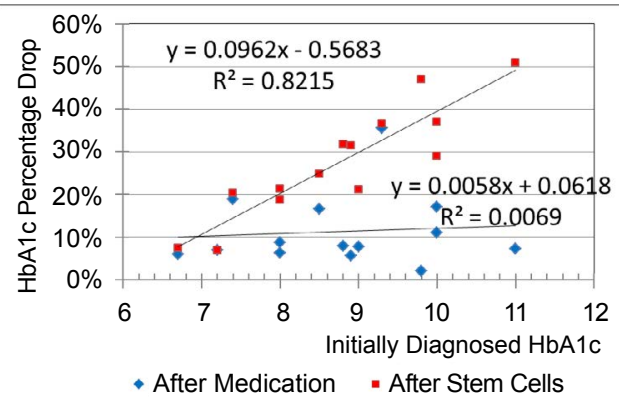

(b)

Figure 6: HbA1c absolute (a) and percentage (b) drop after treatment vs the initially diagnosed HbA1c level.

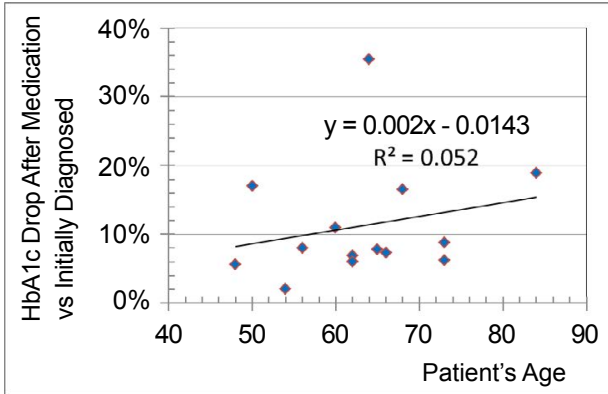

(a)

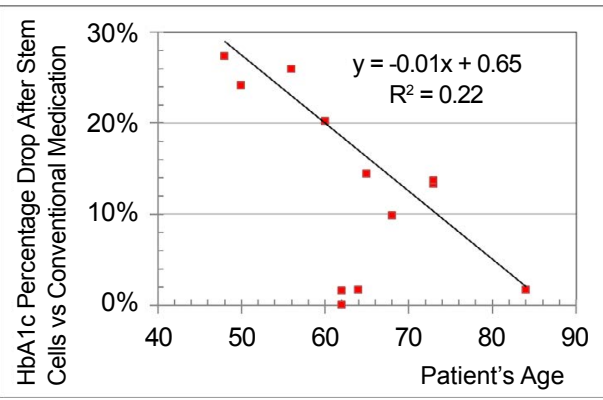

(b)

Figure 7: Correlation of $\mathrm{HbA} 1 \mathrm{c}$ percentage drop after treatment with (a) conventional medications and (b) with stem cells against patient's age. 
Citation: Gargiulo C, Pham VH, Thao HD, Trieu VLH, Kieu NCD, et al. (2016) Human Peripheral Blood Stem Cells can be a Solution to Diabetes Mellitus Type 2 a Preliminary Study on 14 Patients. J Stem Cell Res Ther 6: 354. doi: 10.4172/2157-7633.1000354

Page 8 of 9

entire PB-SCs populations may have a significant part in the whole sequence of repairing and regenerating process, and it is likely that definite combinations of progenitor cells will be required, as will the simultaneous optimization of the diabetic environment into which these cells will be engaged. Such a complex approach will likely be needed to optimally treat diabetic patients with immune-inflammatory and infectious complications.

To conclude, we are well aware that there were several limitations of our study. First, the limited number of participants with autologous PB-SCs was due to the real spirit of fact that only few patients would be able to receive this new style of therapy. We have determined that there are several challenges when it comes to this type of transplant in recently diagnosed DM2, from which the main one is to investigate the length of the clinical response and relapse mechanism. Adjunctive limitations are costly procedures and the strong will of the patient to maintain a proper diet regime constant during the post-treatment time. Actually, we would like to recruit higher number of patients from multi-centers in the future study with more stringent criteria in order to better estimate and assess the use and the validity of autologous PBSCs treatment, for this scope we would like to collect more information such as working activity, daily stress life, telomere length (before/ after treatment). As we infused a mixture of SCs rather than one kind of stem cells the mechanism would be illustrated more deeply.

\section{Acknowledgements}

The authors would like to thank the following for helping to proceed the current project Mr. Do Viet Hung.

\section{References}

1. Son TLND, Kusama K, Shigeru Y (2005) A Community based Picture of Type 2 Diabetes Mellitus in Vietnam. J Atheroscler Thromb 13: 16-21. [PubMed]

2. Trivanović D, Kocić J, Mojsilović S, Krstić A, llić V, et al. (2013) Mesenchymal stem cells from peripheral blood and umbilical cord Wharton's jelly. Srp Arh Celok Lek 141: 178-186. [PubMed]

3. Bianco P, Riminucci M, Gronthos S, Robey PG (2001) Bone marrow stromal cells: nature, biology, and potential applications. Stem Cells 19: 180-92. [PubMed]

4. Caplan Al (2007) Adult mesenchymal stem cells for tissue engineering versus regenerative medicine. Journal of Cellular Physiology 7: 213-341. [PubMed]

5. Chamberlain G, Fox J, Ashton B, Middleton J (2007) Mesenchymal stem cells: their phenotype, differentiation capacity, immunological features, and potential for homing. Stem Cells 25: 2739-2749. [PubMed]

6. Gimble JM, Guilak F, Nuttall ME, Sathishkumar S, Vidal M, et al. (2008) In vitro Differentiation Potential of Mesenchymal Stem Cells. Transfus Med Hemother 35: 228-238. [PubMed]

7. Wagner W, Wein F, Seckinger A, Frankhauser M, Wirkner U, et al. (2005) Comparative characteristics of mesenchymal stem cells from human bone marrow, adipose tissue, and umbilical cord blood. Exp Hematol 33: 1402-1416. [PubMed]

8. Kassis I, Zangi L, Rivkin R, Levdansky L, Samuel S, et al. (2006) Isolation of mesenchymal stem cells from G-CSF-mobilized human peripheral blood using fibrin microbeads. Bone Marrow Transplant 37: 967-976. [PubMed]

9. Sakaguchi Y, Sekiya I, Yagishita K, Muneta T (2005) Comparison of human stem cells derived from various mesenchymal tissues: superiority of synovium as a cell source. Arthritis Rheum 52: 2521-2529. [PubMed]

10. Gronthos S, Mankani M, Brahim J, Robey PG, Shi S (2000) Postnatal human dental pulp stem cells (DPSCs) in vitro and in vivo. Proc Natl Acad Sci U S A 97: 13625-13630. [PubMed]

11. Wang HS, Hung SC, Peng ST, Huang CC, Wei HM, et al. (2004) Mesenchymal stem cells in the Wharton's jelly of the human umbilical cord. Stem Cells 22 : 1330-1337. [PubMed]

12. Locke M, Feisst V, Dunbar PR (2011) Concise review: human adipose-derived stem cells: separating promise from clinical need. Stem Cells 29: 404-411.

\section{[PubMed]}

13. Patel AN, Genovese J (2011) Potential clinical applications of adult human mesenchymal stem cell (Prochymal ${ }^{\circledR}$ ) therapy. Stem Cells Cloning 4: 61-72. [PubMed]

14. Kiang JG (2016) Characterization and therapeutic uses of adult mesenchyma stem cells. In: Stem Cell Toxicity and Medicine. Wiley \& Sons 288-301.

15. Gargiulo C, Pham VH, Hai NT, Nguyen NCD, Pham VP, et al. (2015) Isolation and characterization of multipotent and pluripotent stem cells from human peripheral blood. Stem Cell Discovery 5: 1-17.

16. El-Badri N, Ghoneim MA (2013) Mesenchymal stem cell therapy in diabetes mellitus: progress and challenges. J Nucleic Acids 2013: 194858.

17. Seewoodhary J, Evans PJ (2013) Diabetes and stem cells: Endogenous effects and reparative mechanisms. British Journal of Diabetes \& Vascular Disease 13: $1-7$.

18. DiPersio JF (2011) Diabetic stem-cell "mobilopathy". N Engl J Med 365: 25362538. [PubMed]

19. Saito H, Yamamoto Y, Hiroshi Y (2012) Diabetes alters subsets of endothelia progenitor cells that reside in blood, bone marrow, and spleen. Am J Physiol Cell Physiol 302: C892-C901. [PubMed]

20. Yao EH, Yu Y, Fukuda N (2006) Oxidative stress on progenitor and stem cells in cardiovascular diseases. Curr Pharm Biotechnol 7: 101-108. [PubMed]

21. Fadini GP, Miorin M, Facco M, Bonamico S, Baesso I, et al. (2005) Circulating endothelial progenitor cells are reduced in peripheral vascular complications of type 2 diabetes mellitus. Journal of American College of Cardiology 45: 14491457. [PubMed]

22. Loomans CJ, de Koning EJ, Staal FJ, Rookmaaker MB, Verseyden C, et al. (2004) Endothelial progenitor cell dysfunction: a novel concept in the pathogenesis of vascular complications of type 1 diabetes. Diabetes 53: 195199. [PubMed]

23. Yang G, Lucas R, Caldwell R, Yao L, Romero MJ, et al. (2010) Nove mechanisms of endothelial dysfunction in diabetes. J Cardiovasc Dis Res 1 59-63. [PubMed]

24. Volarevic V, Arsenijevic N, Lukic NI, Stoj M (2011) Concise review: Mesenchymal stem cells treatment of the complication of diabetes mellitus. Stem Cells 29: 5-10. [PubMed]

25. Tang DQ, Cao LZ, Burkhardt BR, Xia CQ, Litherland SA, et al. (2004) In vivo and in vitro characterization of insulin-producing cells obtained from murine bone marrow. Diabetes 53: 1721-1732. [PubMed]

26. Chen LB, Jiang XB, Yang L (2004) Differentiation of rat marrow mesenchymal stem cells into pancreatic islet beta-cells. World J Gastroenterol 10: 3016-3020. [PubMed]

27. Volarevic V, Al-Qahtani A, Arsenijevic N, Pajovic S, Lukic ML, et al. (2010) Interleukin-1 receptor antagonist (IL-1Ra) and IL-1Ra producing mesenchymal stem cells as modulators of diabetogenesis. Autoimmunity 43: 255-263. [PubMed]

28. Xie QP, Huang H, Xu B, Dong X, Gao SL, et al. (2009) Human bone marrow mesenchymal stem cells differentiate into insulin-producing cells upon microenvironmental manipulation in vitro. Differentiation 77: 483-491. [PubMed]

29. Sun Y, Chen L, Hou XG, Hou WK, Dong JJ, et al. (2007) Differentiation of bone marrow-derived mesenchymal stem cells from diabetic patients into insulinproducing cells in vitro. Chinese Medical Journal 120:771-776. [PubMed]

30. Brand-Miller J, Hayne S, Petocz P, Colagiuri S (2003) Low glycemic index die in the management of diabetes a meta-analysis of randomized controlled trials. Diabetes Care 26: 2261-2267. [PubMed]

31. American Diabetes Association (2002) Evidence-based nutrition principles and recommendations for the treatment and prevention of diabetes and related complications. Diabetes Care 25: 202-212. [PubMed]

32. The Diabetes and Nutrition Study: Group of the European Association for the Study of Diabetes (EASD) (2000) Recommendations for the nutritiona management of patients with diabetes mellitus. European Journal of Clinical Nutrition 54: 353-355.

33. Radulian G, Rusu E, Dragomir A, Posea M (2009) Metabolic effects of low glycaemic index diets. Nutr J 8: 1475-289. [PubMed] 
Citation: Gargiulo C, Pham VH, Thao HD, Trieu VLH, Kieu NCD, et al. (2016) Human Peripheral Blood Stem Cells can be a Solution to Diabetes Mellitus Type 2 a Preliminary Study on 14 Patients. J Stem Cell Res Ther 6: 354. doi: 10.4172/2157-7633.1000354

34. Feisst $\mathrm{V}$, Meidinger S, Locke MB (2015) From bench to bedside: use of human adipose-derived stem cells. Dovepress 8: 149-162. [PubMed]

35. de Vasconcellos Machado C, da Silva Telles PD, Nascimento ILO (2013) Immunological characteristics of mesenchymal stem cells. Rev Bras Hematol Hemoter 35: 62-67. [PubMed]

36. Allers K, Hütter G, Hofmann J, Loddenkemper C, Rieger K, et al. (2010) Evidence for the cure of HIV infection by CCR $5 \Delta 32 / \Delta 32$ stem cell transplantation. Blood 117: 2791-2799 [PubMed]

37. Joshi N, Caputo GM, Weitekamp MR, Karchmer AW (1999) Infections in patients with diabetes mellitus. New England Journal of Medicine 341: 19061912.

38. Giovannucci E, Harlan DM, Archer MC, Bergenstal RM, Gapstur SM, et al (2010) Diabetes and cancer: a consensus report. Diabetes Care 33: 1674 1685. [PubMed]
39. Jarajapu YPR, Grant MB (2010) The Promise of Cell-Based Therapies for Diabetic Complications Challenges and Solutions. Circ res 106: 854-869. [PubMed]

40. Morgan CL, Peters JR, Currie CJ (2010) The changing prevalence of diagnosed diabetes and its associated vascular complications in a large region of the UK. Diabet Med 27: 673-678. [PubMed]

41. Stegenga ME, van der Crabben SN, Blümer RM, Levi M, Meijers JC, et al. (2008) Hyperglycemia enhances coagulation and reduces neutrophil degranulation, whereas hyperinsulinemia inhibits fibrinolysis during human endotoxemia. Blood 112: 82-89. [PubMed]

42. Gorbunov NV, Elliott TB, McDaniel DP, Zhai M, et al. (2015) Mitophagy and mitochondrial remodeling in mouse mesenchymal stromal cells following a challenge with Staphylococcus epidermidis. Journal of Cell and Molecular Medicine 19: 1133-1150. [PubMed] 